\title{
Mid Holocene maritime economy in the western Torres Strait
}

\author{
DUNCAN WRIGHT
}

Keywords: Torres Strait, archaeology, marine subsistence, mid Holocene, island formation

\begin{abstract}
Results from a new mid Holocene site in the central-western Torres Strait, north-eastern Australia are presented. AMS determinations from Dabangai on Mabuyag provide evidence for two settlement periods. Phase 1 (7180-4960 calBP) is associated with recurring/ permanent occupation involving marine-based subsistence during the poorly documented period of marine transgression. Phase 2 (230BP-present) is a period of increased site use including an escalation of marine subsistence activities. Results provide the first direct evidence for marine settlement and subsistence practices on Torres Strait islands after their initial formation.
\end{abstract}

In island studies, the transition between open and closed boundaries (i.e. land bridge to island) is expected to result in major physical and conceptual shifts in a resident community (Keegan and Diamond 1987). This may involve altered settlement (frequently abandonment) or alternatively the implementation of adaptive patterns of behaviour capable of dealing with new ecological constraints and/or possibilities (Fitzpatrick 2007). Indicators include altered subsistence practices (e.g. a greater focus on marine resources) and/or the development of new technologies and strategies for managing ecosystems (e.g. burning regimes and specialised subsistence strategies, Fitzpatrick 2007; Nunn 2003).

In the Australian region significant social transformations occurred during the period of shallow-shelf inundation and island formation. Previous studies suggest variable human responses with behaviour "not necessarily explicable in terms of models derived from either 'common sense', or the behaviour of other animal species" (Bowdler 1995: 956). In the majority of cases island formation results in significant reductions in site use or abandonment for several thousand years (O'Connor 1992; Sim and Wallis 2008; cf. Barker 2004). Marine transgression is further expected to influence subsistence economies with marine resources becoming increasingly prominent (Barker 2004; Hall and McNiven 1999; O'Connor and Veth 2000). Data are scattered, however, leaving human responses to island formation and environmental stabilisation in Australia a subject for ongoing debate (Barker 2004: 146; O'Connor 1992: 58; Sim and Wallis 2008: 104).

The Torres Strait Islands (north-eastern Australia) offer

Department of Geography and Environmental Science, Monash University, VIC 3800. Duncan.wright@arts.monash. edu significant potential for addressing this point. During the Last Glacial Maximum (26,500-19,000 years ago) the Western and Eastern high islands of present-day Torres Strait formed peaks and ridges which extended approximately $150 \mathrm{~km}$ between Australia and New Guinea (Barham 1999; Clark et al. 2009; Willmott et al. 1973; Woodroffe et al. 2000). Based on sea level curves, swamp cores and coral dates this mountain range was breached sometime between 9000-7000 years ago (Chappell 2005: 525; Larcombe et al. 1995; fig. 1). After a sea level highstand (approximately 6000 years ago) seas dropped to their current level within the past 4000-3000 years ago. Barham (2000: 291) predicted that the limited areas of platform/ fringing reefs (between 7500-6500 years ago) were destabilised during a "high energy window" between 6500-5000 years ago. Beach progradation and sea-grass/ reef development occurred after 4000 years ago (Barham 2000: 290-92; Barham and Harris 1983: fig. 1; Woodroffe $e t$ al. 2000). During this period (3500-3000 years ago) mangrove forests which had expanded prior to marine transgression decreased dramatically (Barham 1999; Rowe 2007).

Until recently there was no evidence for human activity in the Torres Strait during the marine transgression. It was hypothesised that Islander communities were "ill equipped to deal with insularity" and perished or abandoned their island homes (Rowland 1985: 131). It was further suggested that sustained settlement required sheltered living space and predictable subsistence economies which were not available until 4000BP (Barham 2000: 290; Fuentes et al. 2009; Marsh and Kwan 2007). The only evidence for midHolocene settlement occurs on Badu in the central-western islands (David et al. 2004). Excavations of an inland cave (Badu 15) suggested three settlement phases: permanent occupation (8000-6500 calBP), sporadic visitation from Cape York (6000-3500 calBP) followed by a Papuan expansion after 3500 calBP (David et al. 2004: 75). After 3800BP new sites, containing the earliest evidence for marine subsistence practices, were established on adjacent Berberass (Badu 19) and Pulu (Mask Cave) (Crouch et al. 2007; McNiven et al. 2006).

While evidence is broadly supportive of Barham's (2000) and Rowland's (1985) theories, the paucity of mid Holocene sites leaves the Torres Strait settlement chronology (including human responses to island formation) in doubt (Barham et al. 2004: 39, 41). Using results from excavations on Mabuyag in the central-western Torres Strait these ideas can be readdressed. 


\section{Mabuyag}

Mabuyag (Mabuiag) is a small $\left(8 \mathrm{~km}^{2}\right)$, granitic island which lies at the most northerly point of western Torres Strait (Fig. 1). Chappell (2005: 525) suggests that this island was the northern-most point of the Australian peninsula after initial flooding of the land-bridge between Cape York and New Guinea. The interior of Mabuiag is steep and consists of thin, acidic soils while the coast alternates between mud and sand-flats and rocky peninsulas (Barham 2000; Rowe 2005: 87). The coastal sediments along the east and west coasts of Mabuyag appear to have developed during the late Holocene (Wright 2010).

Dabangai is an ethnographically-significant 'village' situated in a deep embayment on the northeast coast of Mabuyag (Haddon 1904; Eseli et al. 1998). This site contains abundant archaeological features including mound and ditch fields, stone arrangements and bone/shell mounds (Barham and Harris 1987: 28; McNiven and Bedingfield 2008). A large, dugong bone mound was associated with ritual activity connected to the dugong (dhangal) clan and radiocarbon dated to 400-100 calBP (McNiven and Bedingfield 2008).

\section{Excavation}

In September 2006 a 1x1 metre unit (Square A) was excavated 55 metres away from (and 12 metres above) the current high water mark in an area of abundant midden

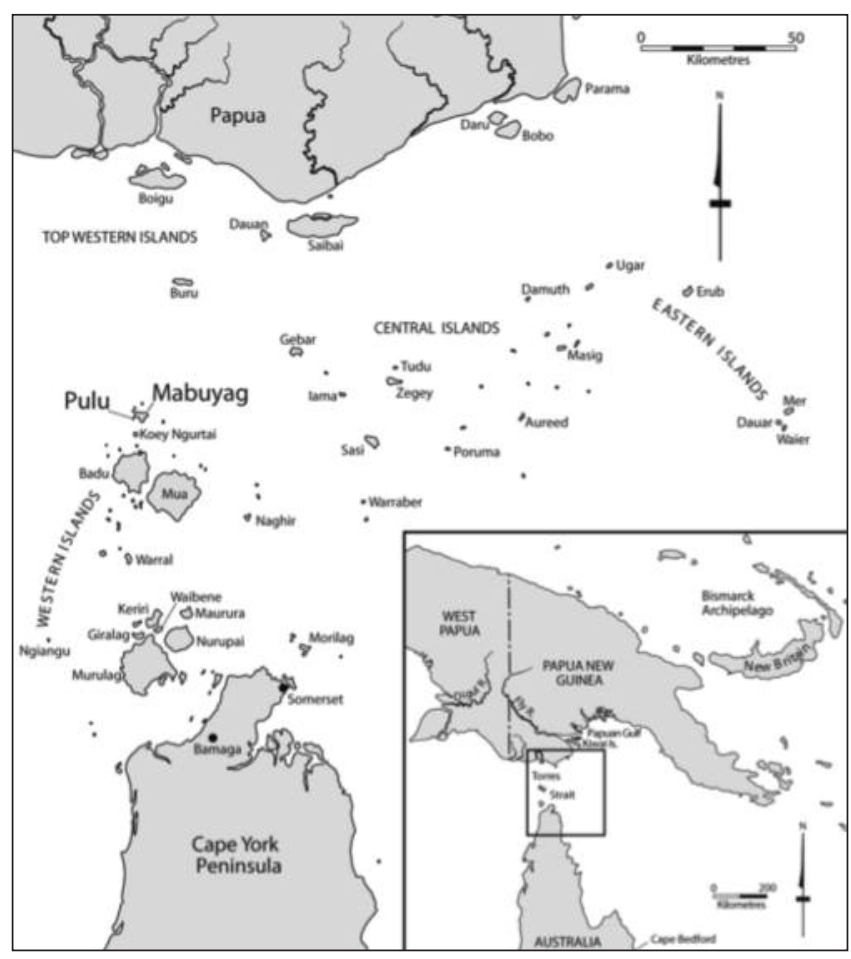

Figure 1. The location of Mabuyag in the western Torres Strait.

bone. It was excavated to a depth of $92 \mathrm{~cm}$ at which point the area was reduced to $40 \times 40 \mathrm{~cm}$ in the northeast corner (Fig. 2). This was necessary due to time constraints and

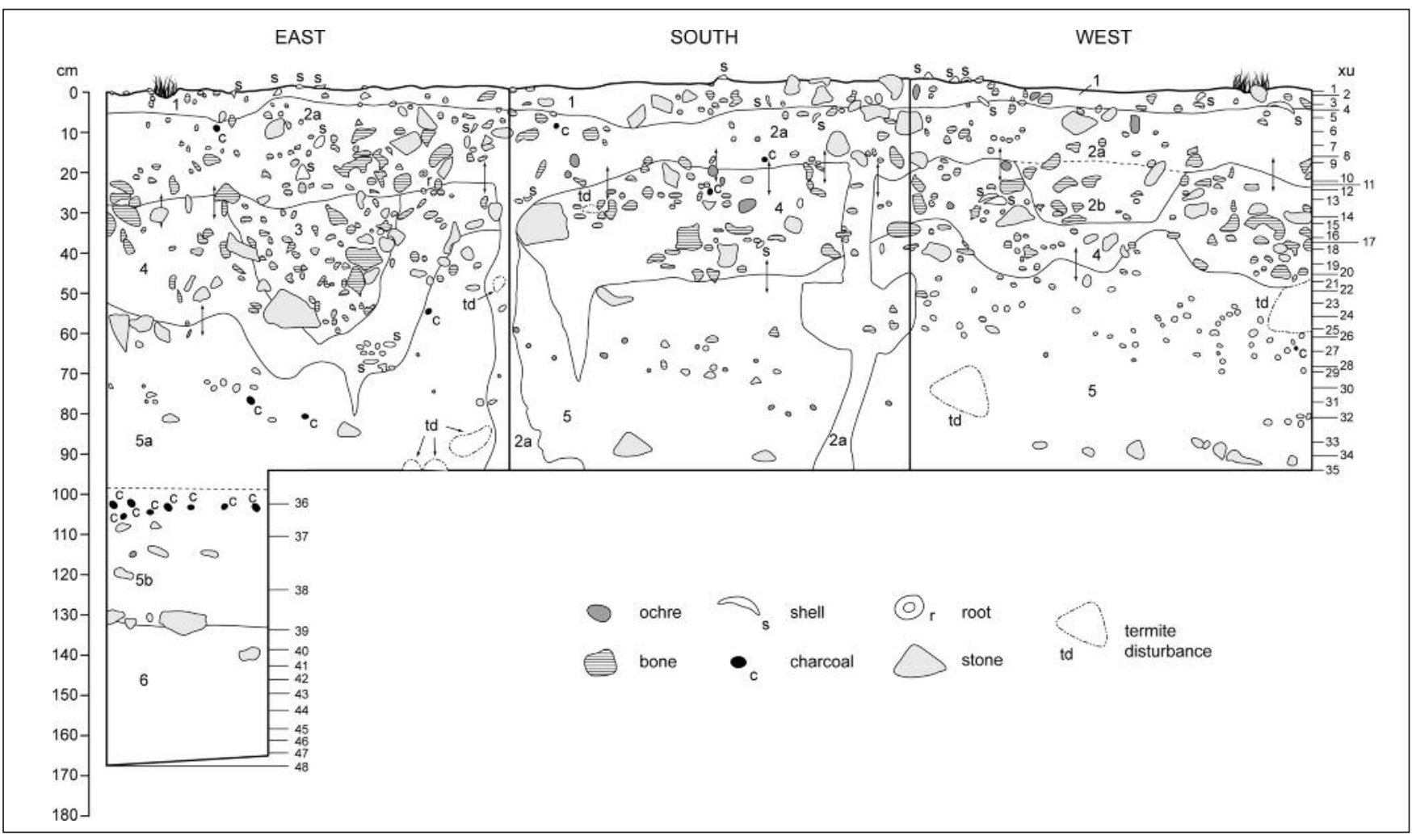

Figure 2. Stratigraphic section, Square A, Dab 1. 
increasingly cemented composition. The unit continued for a further $77 \mathrm{~cm}$ to a maximum depth of $169 \mathrm{~cm}$ before confined space forced its discontinuation before culturally sterile deposits were reached. Where possible Excavation Units (XUs) followed stratigraphy with excavated sediments weighed and dry sieved in the field through a 2.1 $\mathrm{mm}$ mesh. The weight and volume of each XU was recorded and depth elevations were taken at the corners and centre of each square at the beginning and end of each XU. This paper focuses on the oldest and most comprehensively dated cultural sequence from the site.

Localised disturbance (primarily termite activity) was prevalent throughout Layers 1 to 4 and was further observed in the mixed zone between Layers 4 and 5a. Layer 5 b and 6 contain no evidence for post-depositional movement with sediment cemented into a calcite conglomerate. In Layers $5 \mathrm{~b}$ and 6 there were intact lenses of charcoal (XU36), stone (XU39) and pumice (XU41).

Eight in situ samples of charcoal were selected to date key stratigraphic changes, archaeological features and to test the extent of site disturbance (cf. Wright 2010). Two settlement phases were observed, marked by quantitative and to a lesser extent qualitative shifts in cultural materials (Table 1). A mid Holocene settlement phase (spanning 7180-4960 calBP at 20) was identified between 90-169 cmbs (Table 1). This broadly correlates with a transition between Layers $5 \mathrm{a}$ and $5 \mathrm{~b}$, marked by increasingly cemented sand (Fig. 2). Charcoal samples were obtained from an intact lens of charcoal spanning the unit (Layer 5a) and from in situ samples from Layer 6 (Table 1). Samples of turtle and fish bone were submitted to ascertain whether or not these materials were intrusive. A fragment of calcined large vertebrate bone (probable turtle) confirms the provenance of marine vertebrates in Layer 6. No chronological inversions occur in the AMS dates from layers $5 \mathrm{~b}$ and 6 .

The mid-Holocene occupation (XUs 35-48) was associated with $239.5 \mathrm{~kg}$ of deposit accumulating at a rate of between $0.11 \mathrm{~kg}$ and $0.15 \mathrm{~kg}$ per year (Wright 2010). This contained $43.9 \mathrm{~g}$ of degraded large vertebrate bone. The small size of large vertebrate bone made classification to species level problematic. Based on bone morphology and porosity, the majority (55\%) was categorised as 'probable turtle', $18 \%$ of which was observed to be burnt (F. Petchey pers. com. 20 Sept 2010). Minimal quantities of small vertebrate bone $(1.5 \mathrm{~g})$ and fish bone $(0.8 \mathrm{~g})$ were also recorded. All fish bone belonged to small individuals. Between XUs 35-48 there were large quantities of charcoal $(103.8 \mathrm{~g})$, the majority of which clustered between XUs 45 and 47. Between XUs 35-48, 289 quartz and 40 granite stone artefacts were excavated, including five large granite flakes (mean weight $11.2 \mathrm{~g}$, maximum dimension $7.8 \mathrm{~cm}$ ). These flakes were substantially larger than any other igneous artefacts excavated at Dabangai and await further analysis (including examination of residues).

A late Holocene settlement phase (XUs 1-34) was marked by a significant increase in sedimentation rates (3.54-41.32 g/year) and cultural materials. A single date of 175 \pm 40 BP (OZM308) was obtained from XU30 (beneath midden materials) providing a maximum date for midden development. Stratigraphic inversions in the AMS determinations exist in Layers 1 to 4, however all carbon samples date to within the past 230 years (Table 1). This range can be readily explained through rapid sedimentation and the burning of old wood. Layers 1 to 4 contained midden quantities of cultural materials (Fig. 2) and included shellfish, large vertebrates (dugong and turtle), small vertebrates (fish, shark, ray, bird) and European materials (metal, glass, clay pipe and ceramics). There were also 16,378 quartz and igneous flaked stone artefacts, four pieces of ground stone and ochre and a pit feature containing significant quantities of fish bone. Charcoal reduced substantially from $12.6 \mathrm{~g} /$ litre of deposit (XUs 48-41) to $0.7 \mathrm{~g}$ (XUs 40-1). This upper deposit is described in greater detail in Wright and Jacobsen (in press).

\section{Discussion}

It is clear that localised disturbance occurs in the upper excavation layers (Layers 1-5a) at Dabangai. The basal layers (5b and 6) appear to maintain stratigraphic integrity

\begin{tabular}{|c|c|c|c|c|c|c|c|c|}
\hline $\begin{array}{l}\text { Laboratory } \\
\text { Code }\end{array}$ & $\begin{array}{l}\text { Excavation } \\
\text { Unit }\end{array}$ & $\begin{array}{l}\text { Depth below } \\
\text { surface }(\mathrm{cm})\end{array}$ & $\begin{array}{l}\text { Sample } \\
\text { type }\end{array}$ & $\begin{array}{l}\text { Sample } \\
\text { weight }(g)\end{array}$ & $\begin{array}{l}\text { C13\%o } \\
\text { (bp) }\end{array}$ & $\begin{array}{l}\text { C14 Age } \\
\text { BP } 1 \sigma^{*}\end{array}$ & $\begin{array}{l}\text { Calibrated age } \\
\text { BP } 2 \sigma^{*}\end{array}$ & Calibrated age \\
\hline WK24928 & 9 & $16-18$ & Burnt seed & 0.43 & $23.4 \pm 0.2$ & $197 \pm 30$ & $230-160$ & $230-140$ \\
\hline WK24929 & $19 \mathrm{~A}$ & $40-43$ & Charcoal & 0.23 & $25 \pm 0.2$ & $247 \pm 30$ & $300-280$ & $220-150$ \\
\hline WK25437 & $25 \mathrm{~A}$ & $56-59$ & Charcoal & 0.2 & $25.4 \pm 0.2$ & $142 \pm 30$ & $40-0$ & $150-0$ \\
\hline OZM308 & 30 & $70-73$ & Charcoal & 0.2 & $24.9 \pm 0.1$ & $175 \pm 40$ & $120-60$ & $130-0$ \\
\hline WK25438 & 35 & $90-93$ & Charcoal & 0.46 & $25.4 \pm 0.2$ & $4510 \pm 30$ & $5270-5180$ & $5150-4960$ \\
\hline OZM309 & 36 & 102 & Charcoal & 0.3 & NDA & $5530 \pm 100$ & $6400-6180$ & $6450-6000$ \\
\hline OZM310 & 39 & 124-131 & Charcoal & 0.3 & $23.6 \pm 0.3$ & $5510 \pm 45$ & $6250-6210$ & $6320-6180$ \\
\hline WK 28931 & 46 & $162-164$ & Burnt bone & 8.0 & $9.8 \pm 0.2$ & $6005 \pm 30$ & $6417-6298$ & $6495-6260$ \\
\hline OZM311 & 48 & $166-169$ & Charcoal & 0.2 & NDA & $6160 \pm 80$ & $7030-6890$ & $7180-6770$ \\
\hline
\end{tabular}

Table 1: AMS radiocarbon dates, Square A, Dab 1. Calibrations calculated using Calib 6.0.2, Southern Hemisphere/Marine09 (Stuiver and Reimer. 1993). Marine Reservoir $=50 \pm 47 . *$ highest probability of calibrated ranges. $\mathrm{NDA}=$ no data available. 
with intact lenses of charcoal, stone and pumice observed and radiocarbon samples retaining correct chronostratigraphic order. The same is presumably also the case for stone flakes which are considered too large to have trickled down into apparently undisturbed sediment of Layers $5 \mathrm{~b}$ and 6. A mid-Holocene radiocarbon date from burnt bone confirms the provenance of large marine vertebrate bone. While it is conceivable that fragments of small vertebrate bone were intrusive the absence of other small-sized, late Holocene cultural materials (e.g. shellfish, European artefacts) and the integrity of radiocarbon samples suggest that this was not the case.

The Dabangai excavation identifies mid-Holocene settlement on Mabuyag in the western Torres Strait. Between 7180-4960 calBP human activity involved the manufacture of lithics, varied marine subsistence practices and substantial burning regimes. Small quantities of marine vertebrates (fish and turtle and/or dugong) were recovered in basal layers. A radiocarbon date from large vertebrate bone and undisturbed basal strata indicates that marine vertebrates were not intrusive and therefore represent the earliest recorded direct evidence for marine subsistence in the Torres Strait.

Archaeology firmly supports oral and European histories which identify a Goemulgaw (the current Traditional Owners) camp at Dabangai (Gill 1876: 202; Moresby 1876: 13). Radiocarbon dates cluster within the past 230 years (i.e. immediately prior to, or at the same time as, Europeanperiod activity at the site). During this period there was an increase in marine subsistence activities including dugong and turtle hunting, fishing and shellfishing, and the addition of tiger sharks and rays to the subsistence economy.

The Dabangai settlement chronology is very different from Badu 15, where a reduction in artefact densities between 6500-3500 calBP was interpreted as evidence for a decline in site use (David et al. 2004). On adjacent Mabuyag human activities occurred during the period of marine transgression and sea-level high stand (7180-4960 calBP) including Barham's (2000: 291) "high energy window" (6500-5000 years ago). At Dabangai this was followed by a reduction in settlement activity for approximately 5000 years. This is different to Badu 15 and Berberass where increased settlement and marine specialisation occurs after 4000 years ago. Despite the proximity of western Torres Strait islands, evidence supports significant regional variation in human responses to marine transgression.

The recovery of marine vertebrates from undisturbed mid-Holocene layers allows us to reexamine maritime societies in the Torres Strait. Results suggest pockets of marine and terrestrial environments (beaches, reefs, seagrass beds) survived the high energy window arising from marine transgression and that people were suitably equipped to adapt to new ecological constraints and possibilities encountered in these transformed environments. Marine transgression is expected to have necessitated new subsistence technologies and strategies for resident Torres Strait Islander populations. The presence of turtle, fish and possibly dugong bone at Dabangai indicates that the complex maritime economies evident at Badu 19 and Mask
Cave developed after 3000 years of experimentation and innovation following marine transgression.

As with many Torres Strait islands suitable land for contemporary infrastructure development is scarce on Mabuyag. Two months after excavations were completed at Dabangai a waste dump measuring 60x90 metres was established adjacent to the Square A excavation pit. This highlights the pressing need for both cultural heritage impact assessments in the region and archaeological research into early to mid-Holocene coastal environments in the Torres Strait. Barham et al. (2004: 39, 41) acknowledge a bias in research towards late Holocene terrain and highly visible surface deposits. They suggest that "existing survey information is inadequate to exclude the possibility of earlier Holocene human occupation" and predict that earlier sites may be found on low energy beach deposits and behind accretionary coastal barriers (e.g. swamp systems) in the Western Torres Strait (Barham et al. 2004: 40; also David et al. 2004: 66). This was confirmed during surveys on the south-east coast of Badu, with quartz artefacts observed eroding from a mid-Holocene sand dune (Barham pers. com. 05/09/2010). Excavating these coastal deposits is likely to provide much needed clarity into human responses to the transition between land-bridge and island in the Torres Strait.

\section{Acknowledgements}

I would like to thank AIATSIS for funding the project and Monash University for PhD scholarship. Thanks to ANSTO and Monash University for providing funding to redate the Dabangai site. Further thanks go to Traditional Owners of Dabangai (Dhangal clan) and the Mabuyag community for their ongoing support. Thanks also to the field crew: Beboy Whap, Thomas Whap, Ben Watson and Cameo Daley as well as Tim Denham, Garrick Hitchcock, Ian McNiven and Jeremy Ash for reading drafts of this paper. Kara Rasmanis and Toby Wood are thanked for their assistance with illustrations.

\section{References}

Barham, A 1999. The local environmental impact of prehistoric populations on Saibai Island, northern Torres Strait, Australia: enigmatic evidence from Holocene swamp lithostratigraphic records. Quaternary International, 59, 71-105.

Barham, AJ 2000. Late Holocene maritime societies in the Torres Strait Islands, northern Australia - cultural arrival or cultural emergence? In S O'Connor and P Veth (eds), East of Wallace's Line: studies of past and present maritime cultures of the IndoPacific Region. Modern Quaternary Research in Southeast Asia (Vol. 16, pp. 223-314). Rotterdam: A.A Balkema.

Barham, A and Harris, D (eds) 1983. Prehistory and Palaeoecology of Torres Strait. London: Academic Press.

Barham, A, Roland, M and Hitchcock, G 2004. Torres Strait bepotaim: An overview of Archaeological and Ethnoarchaeological investigations and research. In IJ McNiven \& M Quinnell (eds), Torres Strait Archaeology and Material Culture (Vol. 3, pp. 1-72) Brisbane: Memoirs of the Queensland Museum Cultural Heritage Series. 
Barker, B 2004. The Sea People: Late Holocene Maritime Specialisation in the Whitsunday Islands, Central Queensland (Terra Australis Vol. 20). Canberra: Pandanus Books.

Bowdler, S 1995. Offshore islands and maritime explorations in Australian prehistory. Antiquity 69: 945-58.

Chappell, J 2005. Geographic changes of coastal lowlands in the Papuan past. In A Pawley, R Attenborough, J Golson and R Hide (eds), Papuan Pasts: Cultural, Linguistic and Biological Histories of Papuan-Speaking Peoples (pp. 525-539). Canberra: Research School of Pacific and Asian Studies, ANU.

Clark, PU, Dyke, AS, Shakun, JS, Carlson, AE, Clark, J, Wohlfarth, B, Mitrovica, JX, Hostetler, SW and McCabe, AM 2009. The Last Glacial Maximum. Science 7, 325(5941): 710714.

Crouch, J, McNiven, IJ, David, B, Rowe, C and Weisler, M 2007. Berberass: marine resource specialization and environmental change in Torres Strait during the past 4000 years. Archaeology in Oceania, 42: 49-64.

David, B, McNiven, IJ, Mitchell, R, Orr, M, Haberle, S, Brady, L, and Crouch, J 2004. Badu 15 and the Papuan-Austronesian settlement of Torres Strait. Archaeology in Oceania, 39: 65-78.

Eseli, P, Shnukal, A and Mitchell, R 1998. Eseli's Notebook. Aboriginal and Torres Strait Islander Studies Unit Research Report Series (Vol. 3). Brisbane: University of Queensland Press.

Fitzpatrick, SM 2007. Archaeology's Contribution to island Studies. Journal of Island Studies, 2: 77-100.

Fuentes, M, Limpus, C, Hamann, M and Dawson, J 2009. Potential impacts of projected sea-level rise on sea turtle rookeries. Aquatic Conservation, 22: 132-139.

Gill, W 1876. Life in the southern isles; or, scenes and incidents in the South Pacific and New Guinea. London: The Religious Tract Society.

Haddon, AC 1904. Reports of the Cambridge Anthropological Expedition to Torres Straits: Sociology, Magic and Religion of the Western Islanders. (Vol. 5). Cambridge: Cambridge University Press.

Hall, J and McNiven, IJ (eds), 1999. Australian Coastal Archaeology (Research Papers in Archaeology and Natural History Vol. 31). Canberra: ANH Publications, Department of Archaeology and Natural History, Australian National University.

Keegan, WF and Diamond, J 1987. Colonization of Islands by Humans: A Biogeographical Perspective. Advances in Archaeological Method and Theory, 10: 49-92.

Larcombe, P, Carter, RM, Dye, J, Gagan, MK and Johnson, DP 1995. New evidence for episodic post-glacial sea-level rise, central Great Barrier Reef, Australia. Marine Geology, 127: $1-44$

Marsh, H and Kwan, D 2008. Temporal variability in the life history and reproductive biology of female dugongs in Torres
Strait: The likely role of sea grass dieback. Continental Shelf Research, 28: 2152-2159.

McNiven, IJ and Bedingfield, A 2008. Past and present marine mammal hunting rates and abundances: dugong (Dugong dugon) evidence from Dabangai Bone Mound, Torres Strait. Journal of Archaeological Science, 35: 505-515.

McNiven, IJ, Dickinson, WR, David, B, Weisler, F, Carter, M and Zoppi, U 2006. Mask Cave: Red-slipped pottery and the Australian-Papuan settlement of Torres Strait, Archaeology in Oceania, 41: 49-82.

Moresby, J. 1876. New Guinea and Polynesia: Discoveries and Surveys in New Guinea and the D'Entrecasteaux Islands. London: John Murray.

Nunn, PD 2003. Nature-society Interactions in the Pacific islands, Geografiska Annaler, 85: 219-229.

O'Connor, S 1992. Timing and nature of prehistoric island use in northern Australia, Archaeology in Oceania 27: 49-60.

O'Connor, S and Veth, P 2000. The world's first mariners: savannah dwellers in an island continent. In S O'Connor and P Veth (eds), East of Wallace's Line: Studies of Past and Present Maritime Cultures of the Indo-Pacific Region Modern Quaternary Research in Southeast Asia (Vol. 16 pp. 99-137). Rotterdam: AA Balkema.

Rowe, C 2005. A Holocene History of Vegetation Change in the Western Torres Strait Region, Queensland Australia. Unpublished $\mathrm{PhD}$ thesis, Monash University, Melbourne.

Rowland, MJ 1985. Archaeological investigations on Moa and Naghi Islands, Western Torres Strait. Australian Archaeology, 21: 119-132.

Sim, R and Wallis, L 2008. Northern Australian Offshore Island Use During the Holocene: The Archaeology of Vanderlin Island, Sir Edward Pellew Group, Gulf of Carpentaria. Australian Archaeology 67: 95-107.

Willmott, WF, Whitaker, WG, Palfreyman, WD and Trail, DS 1973. Igneous and Metamorphic rocks of Cape York Peninsula and Torres Strait. Bulletin of the Bureau of Mineral Resources, Geology and Geophysics, 135: 113-128.

Woodroffe, CD, Kennedy, DM, Hopley, D, Rasmussen, C and Smithers, SG 2000. Holocene reef growth in Torres Strait. Marine Geology, 170: 331-346.

Wright, D 2010. The archaeology of community emergence and development on Mabuyag in the Western Torres Strait. Unpublished $\mathrm{PhD}$ thesis, Monash University, Melbourne.

Wright, D and Jacobsen, G in press. Convergence of ceremonial and secular: The archaeology of Dabangai on Mabuyag in the western Torres Strait. In IJ McNiven and G Hitchcock (eds) Goemulgal: Natural and Cultural Histories of the Mabuyag Islands, Zenadh Kes (Torres Strait). Memoirs of the Queensland Museum, Cultural Heritage Series. Brisbane: Queensland Museum. 